\title{
CONTEMPORARY ISSUES OF VALUATION: ERRORS AND ABUSES"
}

\section{Semen Yu. BOGATYREV}

Financial University under Government of Russian Federation, Moscow, Russian Federation

sbogatyrev@fa.ru

https://orcid.org/0000-0002-6080-5869

\section{Article history:}

Article No. 173/2019

Received 26 February 2019

Received in revised form 22 March 2019

Accepted 26 April 2019

Available online

25 December 2019

JEL classification: C13, G12

Keywords: cost approach, income approach, comparative approach, cash flows, multipliers

\begin{abstract}
Subject The article reviews misstatements arising from appraisal when three key valuation methods are used, i.e. income, comparative and cost methods. I also focus on valuation practices and instances when the above methods are inconsistent with the theory and adequate information resources.

Objectives I identify key errors and show instances of abuse as part of key valuation methods, and propose methods to assess such instances and prevent misstatements.

Methods The research is based on methods of analysis, synthesis, and formalization in identifying and describing valuation errors.

Results I refer to multiple cases and examples to illustrate the incorrect use of valuation approaches. The article also describes key theoretical provisions of valuation, which should be applied to detect errors and abuses of appraisers and cost analysts. I suggest what mechanisms should be used to prevent valuation abuses and show how modern information systems can work to correct inadequate valuation results.

Conclusions and Relevance In the time of market turbulence, unbalanced information and key indicators, appraisers tend to commit a lot of incidental errors in reports and abuses by deliberately misstating valuation outcomes through manipulations. Referring to such instances identified and described, methods to detect them and proposed measures to adjust valuation procedures for available information, appraisers, cost analysts, users of valuation reports will have precise value benchmarks, compile unbiased economic indicators in order to make adequate managerial decisions.
\end{abstract}

(C) Publishing house FINANCE and CREDIT, 2019

The editor-in-charge of this article was Irina M. Vechkanova

The authorized translation by Irina M. Vechkanova

Please cite this article as: Bogatyrev S.Yu. Contemporary Issues of Valuation: Errors and Abuses. Digest Finance, 2019, vol. 24, iss. 4, pp. 403-408.

https://doi.org/10.24891/df.24.4.403

\section{Introduction}

The practice of detecting appraisal manipulations, risky aspects of valuation procedures that result in misstatements is a crucial and vast matter. To sort out various valuation difficulties and qualify them as errors or deliberate manipulations, appraisers should primarily identify the most frequent errors in valuation, whether they are committed unintentionally or deliberately.

\footnotetext{
"For the source article, please refer to: Богатырев С.Ю. Современные проблемы стоимостной оценки: ошибки и злоупотребления // Финансовая аналитика: проблемы и решения. 2019. Т. 12 . № 4. С. 468-476.

URL: https://doi.org/10.24891/fa.12.4.468
}

Another point is to understand how such errors can be avoided and losses from mala fide valuation can be reduced as low as possible, thus eliminating the effect of a fabricated report.

Such information is mostly relevant to experts who measure someone else's valuation reports. However, it is also useful to appraisers in order to avoid common mistakes.

Appraisers deal with a variety of issues and tasks. Sometimes, difficulties and errors happen so unexpectedly and exuberantly that the above difficulties may seem just a beginning of a long and intriguing story of practical cases, which 
every appraiser and cost analyst come across on their professional path.

\section{Assessment a Sectoral Risk Premium in the Discount Rate}

I analyzed the way the sectoral risk premium is assessed in the discount rate and had the following findings. An appraiser should, first of all, verify the assumption that the premium should range from -3 to 3 percent. For example, it is taken to equal zero. Then, the appraiser reviews factors pro et contra risk and conducts an analysis to check the values.

The formula and its components should imply different risk, without repeating them, when the premium is assessed. The premium for specific risks can include the sectoral risk. No matter what the appraiser might do to assess the premium in the discount rate formula, he/she should justify its computations and give a detailed account in a valuation report.

Committed during the computation of the weighted average discount rate, errors and manipulations are found in the following situations. It is important to use the market value of debt when measuring what kind of capital makes the total. If it is difficult to determine the market value of equity and debt, the controlling share and WACC should be assessed with the market average ratio of debt to total invested capital.

To verify an error or confirm value manipulations in a valuation report, it is necessary to check whether the appraiser has referred to the same public companies as part of a comparable company analysis (CCA) as used to evaluate the composition of capital.

Being both popular in countries other than Russia, formulas of the Discounted Cash Flow (DCF) method and Capitalized Cash Flow (CCF) method measure value through growth.

As part of CCF, a growth influenced the underlying formula:

$V=$ Income $/($ Discount Rate - Growth $)$.

As for DCF, the growth rate is a part of the Gordon Growth Model defining the terminal value, that is the projected value in perpetuity.
As long as a growth may directly influence the value, it is critical to choose a growth rate that can be confirmed depending on the purpose of valuation. The value is often manipulated just when a growth is measured.

Measuring a growth, appraisers mainly have two methods:

- the business's sustainable growth rate;

- the economy's estimated long-term growth rate.

The appraiser's computations can be verified as well through the following assumptions. Neither company demonstrates a continuing growth exceeding that of the overall economy, because, in theory, it will absorb the economy. In fact, corporate indicators can increase at the pace of the entire economy or even be lower. Hence, an economic growth determines the highest possible rate of growth, which a company may reach in perpetuity. This is the way the Gordon Growth Model determines the value. However, an economic growth has two components, i.e. the expected inflation and expected real growth.

\section{Difficulties in Cash Flow Measurements}

Foreign appraisers note that it may be difficult to use cash flows in DCF and CCF methods. Moreover, errors and manipulations are not uncommon. The discount rate accommodates for the risk associated with the result of cash flows. Foreign accounting rules provide for a scenario approach to measuring expected cash flows and subsequent computation of the present value at a risk-free rate [1].

What primarily helps avoid errors as part of the DCF method or value manipulations is the measurement of future cash flows with reference to the current situations. Hence, choosing between forecasted cash flows and projected cash flows, for example, from managers' business plans or CFO's answers, the first option is preferable. Although being the easiest scenario, the projected cash flow implies a plan which depends on certain cost-based requirements. Due to the fact, projected cash flows will not do to measure cash flows for valuation purposes [2].

Foreign appraisers refer to top executives, analytical materials as sources of information 
about cash flows. Evaluating the management's forecasts of expected cash flows, the appraiser should consider the feasibility of such forecasts, verify them retrospectively, reliability of assumptions and inputs.

It is reasonable to evaluate the competence of the analyst who makes forecasts, and confirm the reliability of his assessments of expected cash flows. It is necessary to check whether the analysts does have access to the relevant information for forecasting, the way he/she verifies the information and what assumptions are used for that.

As experts say, errors arise when appraisers do not refer to the balance sheet of an analyzable company or deliberately disregard it, manipulating the value. If possible, the balance and profit should be forecasted concurrently. Then it will be clear whether a company has enough capital to attain profitability targets, how projected cash flows influence the financial leverage and whether computations account for capital expenditures incurred to spur a growth that the projected cash flows may ignite.

Errors occur due to cash flows mixed among the majority (control cash flows) and minority portfolios (minority cash flows) [3]. In theory, the majority cash flows make the value of the majority portfolio, including the control premium. The minority cash flows form the value of the minority portfolio with a control discount. Correspondingly, the value of the majority portfolio should be assessed with reference to control.

It is important, since foreign appraisers happen to disregard control adjustments after the modelbased computations are completed, but rather include them into computations initially. In such circumstances, they should keep in mind that it is unacceptable to duplicate control adjustments in their computations when estimating cash flows and assessing the discount rate.

Considering a different impact of majority and minority shareholders on cash flows, appraisers suggest making a thorough evaluation of a share portfolio, which are so different in size, during the normalization.
If the valuation report indicates the value of a 100-percent interest in the company's capital, neither control premium can be added. Any additional mark-up can me made only for synergy.

In practice, foreign financial analysts examine a borderline case of including the control adjustment, when a 51-percent share in the company's equity is assessed. Is such an adjustment applicable in this case?

The Western community of appraisers voices three opinions.

1. The adjustment is applicable, since the beneficiary may have illegal gains.

2. An opportunity to set an excessive compensation, dividends and other benefits of a controlling portfolio will result in the excess value.

3. A discretionary opportunity to steer the corporate development will result in a control premium.

\section{Analysis of Valuation Issues Through the Cost Method}

The cost approach becomes more and more common not only among the so called red directors $^{1}$ in Russia, but is also very popular in North America for valuing multiple abandoned production facilities and real estate.

As part of the cost approach, the net asset method is frequently used. As appraisers observe in Russia and abroad, this is the most complicated method to use, albeit looking so simple. It requires profound technical and special skills and knowledge. The identification of assets, both tangible and intangible, is one of the challenging tasks appraisers have to deal with using the method.

According to the U.S. appraisers, the net asset method often produces an error causing that the outcome is inconsistent with the type of value specified in the terms of reference. There are the following standards (types) of value:

\section{- reproduction cost;}

\footnotetext{
${ }^{1}$ Top executives who have been professionally raised during the Soviet rule and keep the Soviet style of management.
} 
- replacement cost;

- fair market value;

- fair market value in continued use;

- orderly liquidation value;

- forced liquidation value.

The net asset method often engenders errors that may result from an incorrect choice of methods used to measure intangible assets. The errors stem from the above difficulty in identifying an item of intangible assets.

Other errors are made when the value of goodwill is concerned.

As part of the cost approach, foreign appraisers mention such errors that relate to the excess earnings method. The errors are consequences of the incorrect valuation of tangible assets due to difficulties in measuring the return on assets (ROA). Knowing the ROA (tangible assets), the appraiser subtracts it out of total return and posts the difference to the return on intangible assets.

Appraisers come across errors arising from the incorrect valuation of intangible assets and their return. In theory, the return on intangible assets exceeds the return on tangible assets, being the underlying idea of the method. It is supposed to be this way, but there may be some inconsistencies.

If the appraiser fails to measure the value of debt and subtract it when assessing excess earnings, the value of equity will be incorrect.

Results of the above method cannot be substantially verified at the capitalization rate. The capitalization rate should be identical to that used for the income approach. As a matter of fact, the generic rate produces another result, which differs from the appraiser's expectations as part of the method. The appraiser applies different rates, which is an erroneous decision looking like value manipulations.

\section{Analysis of Contemporary Issues of the Comparative Approach}

Some errors stem from the CCA. Using the CCA method, the appraiser's sample of comparable companies may be insufficient or excessive [4]. It is not a good decision either if the appraiser selects comparable companies which cannot be considered as such by size or sector.

Erroneous results may proceed if it is impossible to make an adjustment or normalize financial statements of comparable companies due to changes in the number of stocks in circulation, one-off losses, fluctuation profit. The comparable approach is known to be problematic because appraisers have to examine not only financial statements of the analyzable company, but also those of comparable companies [5].

Appraisers often select inappropriate multipliers. Multipliers can be incorrectly chosen due to the incompatibility of risk exposures, different qualities of the analyzable company and comparable companies [6].

Other errors occur because appraisers cannot exclude an impact of income and expenses from non-operating assets. The procedure is based on financial statements of the analyzable company. Errors also result because it is impossible to detect and reincorporate non-operating assets and liabilities as part of valuation [7].

The comparable transaction method, or the Merger \& Acquisition method as it is called in the USA, may become a source of the following errors.

When computing some indicators, appraisers may mix different M\&A databases. The fact is that all M\&A databases are identical [8-10]. For example, in Russia a person puts an advertisement in a popular free advertisement website (AVITO) and finds it on many other classifieds in a couple of hours. Such classified create their content by referring to the local data leader as an information pipeline in a certain market segment.

Therefore, the appraiser cannot exclude statistics of recurring data in financial statements concerning the same deals, thus creating statistical duplicates.

Choosing to use several databases, the appraiser should avoid repetitive information. However, at the very beginning he/she should decide whether it is reasonable to include some databases into the data set for valuation purposes. 
Moreover, when calculating multipliers, the appraiser may incidentally mix data on sale of assets and shares ${ }^{2}$ [11]. As a result of the comparable transaction method, the appraiser may assess a multiplier, which has not be agreed and have the discordant numerator and denominator [12].

Computing the average multiplier without processing and analyzing statistical data properly, the analyst may come up with another type of errors arising from the industry formulas method.

Many foreign appraisers do not support the ruleof-thumb method. In the mean time, the method is quite practicable given there are good industry statistics and business practice [5].

As recommended in the U.S. valuation standards, the rule-of-thumb method should not be used alone, but supplemented with other techniques. Hence, it will be possible to check resultant computations and the scope of the result, perform a sanity check [13]. Applying the method, the appraiser should be ready to get an approximate result. However, it depends on an industry. For example, the U.S. dealerships see almost similar sectoral correlations of dealership resales, while results of other valuation methods should be taken into considerations with other industries.

\section{Conclusion}

Currently, appraisers make many unintentional errors in their reports and deliberately distort valuation results through various manipulations. It is necessary to detect and describe such behavior of appraisers, methods to reveal such situations and proposed solutions to adjust valuation procedures for relevant information. Therefore, cost analysis, appraisers, users of valuation reports will get a clear understanding of the value, create an unbiased pool of economic metrics to make reasonable managerial decisions.

\footnotetext{
${ }^{2}$ Mauro B. Implied Cost of Capital: How to Calculate It and How to Use It. URL: https://www.icaew.com/-/ media/corporate/files/technical/corporate- 


\section{References}

1. Grigor'ev V.V. [Specifics of the Discount Rate Calculation in the Business Valuation]. Ekonomika. Nalogi. Pravo = Economics, Taxes \& Law, 2018, vol. 11, no. 3, pp. 83-88.

URL: https://cyberleninka.ru/article/n/osobennosti-protsessa-formirovaniya-stavkidiskontirovaniya-v-otsenke-biznesa (In Russ.)

2. Hitchner J. Calculation Survives Daubert Challenge - Does This Help Open the Door for Calculations in Litigation? Financial Valuation and Litigation Expert Journal, 2014, no. 52, pp. 23-34.

3. Taylor R. Common Mistakes in Valuation Reports. Financial Valuation and Litigation Expert Journal, 2018, no. 75, pp. 78-82.

4. Grossman R. What Is the Level of Value Produced by the Guideline Publicly Traded Company Method? Financial Valuation and Litigation Expert Journal, 2006, no. 6, pp. 67-72.

5. Li D. Expertise versus Bias in Evaluation: Evidence from the NIH. American Economic Journal: Applied Economics, 2017, vol. 9, no. 2, pp. 60-92. URL: https://doi.org/10.1257/app.20150421

6. Balcombe J. Market Approaches Miss the Mark When the Subject Company Has Untransferrable Goodwill. Financial Valuation and Litigation Expert Journal, 2007, no. 6, pp. 45-56.

7. Bobe A. Business Valuation. Adjusting Markets Multiples for Country Risk in Emerging Markets Empirical Study for Romania. The Valuation Journal, 2015, vol. 10, iss. 2, pp. 68-85.

8. Bogatyrev S.Yu. [Applying the newest information systems in the cost analysis]. Kibernetika $i$ programmirovanie = Cybernetics and Programming, 2014, no. 2. (In Russ.)

URL: https://doi.org/10.7256/2306-4196.2014.2.11736

9. Bogatyrev S.Yu. [Cost analysis of shares in Bloomberg Terminal]. Voprosi ocenki, 2014, no. 1, pp. 12-38. URL: http://www.library.fa.ru/files/Bogatyrev.pdf (In Russ.)

10. Grunin A.A., Sagaidachnaya O.V., Bogatyrev S.Yu. [M\&A Information Intelligence with Comfort]. Sliyaniya i pogloshcheniya = Mergers and Acquisitions, 2014, no. 7, pp. 5-18. (In Russ.)

11. Burkert R. On Practice Management: Pricing - Are You Discounting or Negotiating? Financial Valuation and Litigation Expert Journal, 2018, no. 75, pp. 85-92.

12. Bogatyrev S.Yu., Kolosov P.V., Zhurkina T.O. [Approach in appraisal practice in a crisis]. Sliyaniya i pogloshcheniya $=$ Mergers and Acquisitions, 2012, no. 3, pp. 40-44. (In Russ.)

13. Stan S.V. The Economic Postulates of Asset Valuation Practice. The Valuation Journal, 2014, vol. 9, iss. 1, pp. 4-33.

\section{Conflict-of-interest notification}

I, the author of this article, bindingly and explicitly declare of the partial and total lack of actual or potential conflict of interest with any other third party whatsoever, which may arise as a result of the publication of this article. This statement relates to the study, data collection and interpretation, writing and preparation of the article, and the decision to submit the manuscript for publication. 